\title{
ROLE PLAY AS A SOLUTION FOR WIRARAJA NURSE'S SPEAKING ABILITY: ACTION OF REAL LIVE IN NURSING ACTIVITIES
}

Akhmad Feri Fatoni, Program Studi Ilmu Keperawatan Universitas Wiraraja

e-mail:akhmadferi25@gmail.com

Cory Nelia Damayanti, Program Studi IImu Keperawatan Universitas Wiraraja

e-mail: corynelia@wiraraja.ac.id

\section{ABSTRACT}

English as foregn languge attends to be big problem to solve, especially for nurse. Learning focus that positioned English as general course for nurses doesn't subside effective contribution to increase the fluency of theirs english communicaton.

This research is basically aimed to test the nurse's speaking ability by using Role play. Quantitative analysis (quasy-experiment) is used to measure that there are differences in English communication skills in experimental calss and control class, while the populations are fourth semester of wiraraja university's nurse students. Pre-test and post-test were used to measure the improving students's speaking ability.

The result of the data analysis show that the experimental post test's score is higher than control group.. Therefore, it can be conclude that role play improves wiraraja nurses's speaking ability.

\section{Keywords: Role play, speaking ability, nurse}

\section{INTRODUCTION}

Now days, English as international language holds imporant rule especially in eduaction field. Universal knowledge scope requires learner not only to know English, but also to comperhand the using both orally and written. In nursing, English is very important in some cases such as the search for scientific resources, the translation of medical terms, communication with patients, and the process of looking for a job. Nurses will be greatly helped and feel their presence if they are able to use English in every profession interaction especially for those who live in tourism areas that are often visited by foreign tourists such as Sumenep.

As foreign language, more over English as general course for nurse, it became secondary needed of learning process. It comes because most of students argue that English doesn't have direct correlation with nursing. Besides that, learning English takes long time as consequence of it's difficulties to be comperhend.

As known that speaking is the most important skill in English among four other skills, speaking ability takes very important skill to be mastery. Accordig to Ladouse (1991) sepaking is described as the activty as the ability to express and report the situation or activity in prescise words or the ability to converse or to express a sequence of ideas fluently. It means that speaking is skill to express what someone see,feel, and think. When someone see, feel, or think something, automatically he wants someone else to hear about it. Wilson (1983) defines that speaking as development of the relationship between speaker and listener. In order to express effectively, the speaker should know exactly what he wants to speak, he has to be able to evaluate the effect of his communication to the listener, then the listener should get the point what the speaker declare.

As foreign language in Indonesia, English became a laguage which is very rarely to use in communication, especially for nonenglish learner. As known that English is a skill that can be mastery only by practice, the learner has to communicate in English frequentnly. As a solution of problem faced by nurses in mastery English speaking ability, partice to speak English is needed to be held continuosly. According to Qing (2011) trying to interact each other as a projection of real life situation attends to be effective and efficient method in helping students to increase their speaking ability.

Liu and Ding (2009) used role play technique to see how the student performed in groups when they were given a familiar situation to role play in. In detail, role play will be suitable method for this case. The strategy applied must be on targeted and measurable to know the improvement of nurses speaking ability significantly. Therefore, from the 
background, Role play to improve nurse's speaking ability of wiraraja universiy is formulated for this research.

\section{METHOD}

This study employes quantitative analysis (quasy-experiment) research design in increasing wiraraja nurses's speaking ability. According to Creswell (2008, p.313), the design is used because the treatment is not random assignment of participants to groups. It means that there is no selection of population. Data analysis that was gotten from pre-test and post-test can be applied to both experiment and control group (Creswell, 2008, p.314). based on the theory, it ca be said the goups devided into experiment and control group that tested twice both pre-test and pottestThe research design has several characteristics as follows: (a) it has two groups namely experimental and control group; (b) the two groups are compared respectively two measure dependent variable; (c) each groups are tested twice (pre-test and post-test). Scoring instrument are used for pre-test and post-test. As known that speaking is a skill which requires scoring rubric as hint of student's gaining score, so the scoring rubric can be seen as below:

\begin{tabular}{|c|c|c|c|}
\hline NO & Aspecs & Score & Criteria \\
\hline \multirow[t]{4}{*}{1} & Fluency & 50 & Speech is jerky: hardly comprehensible \\
\hline & & 60 & $\begin{array}{l}\text { Speech is frequently halted; frequent unnatural } \\
\text { pauses, fairly comprehensible }\end{array}$ \\
\hline & & 70 & $\begin{array}{l}\text { Speech is mostly fluent; a few unnatural pauses; fairly } \\
\text { comprehensible }\end{array}$ \\
\hline & & 80 & $\begin{array}{l}\text { Speech is very fluent; no unnatural pauses; all } \\
\text { comprehensible }\end{array}$ \\
\hline \multirow[t]{4}{*}{2} & Accuracy & 50 & $\begin{array}{l}\text { Inadequate mastery of grammar and vocabulary, with } \\
\text { frequent inappropiate choice of expression/register }\end{array}$ \\
\hline & & 60 & $\begin{array}{l}\text { Fair master of grammar and vocabulary, with } \\
\text { occasional inappropiate choice expression/register }\end{array}$ \\
\hline & & 70 & $\begin{array}{l}\text { Good mastery of grammar and vocabulary with mostly } \\
\text { appropiate choice of expressions/register }\end{array}$ \\
\hline & & 80 & $\begin{array}{l}\text { Excellent mastery of gramar and vocabulary with all } \\
\text { appropiate choice of experssions/register }\end{array}$ \\
\hline \multirow[t]{4}{*}{3} & Pronounciation & 50 & $\begin{array}{l}\text { Pronunciation is poor and unclear with mostly } \\
\text { incorrect rhythm and stress pattern }\end{array}$ \\
\hline & & 60 & $\begin{array}{l}\text { Pronunciation is fairly intelligible and clear with some } \\
\text { incorrect rhythm and stress pattern }\end{array}$ \\
\hline & & 70 & $\begin{array}{l}\text { Pronunciation is mostly intelligible and clear; with } \\
\text { good rhythm and stress pattern }\end{array}$ \\
\hline & & 80 & $\begin{array}{l}\text { Pronunciation is always intelligible and clear; with } \\
\text { good rhythm and stress pattern }\end{array}$ \\
\hline \multirow[t]{4}{*}{4} & Performance & 50 & $\begin{array}{l}\text { Posture, gesture, facial expression, eye contact, and } \\
\text { volume demonstrate poor performance }\end{array}$ \\
\hline & & 60 & $\begin{array}{l}\text { Posture, gesture, facial expression, eye contact, and } \\
\text { volume demonstrate fair performance }\end{array}$ \\
\hline & & 70 & $\begin{array}{l}\text { Posture, gesture, facial expression, eye contact, and } \\
\text { volume demonstrate good performance }\end{array}$ \\
\hline & & 80 & $\begin{array}{l}\text { Posture, gesture, facial expression, eye contact, and } \\
\text { volume demonstrate excellent performance }\end{array}$ \\
\hline
\end{tabular}

\section{RESULT}

The result of study are the results of treatment were given showed quantativelly by pre-test and post-test. A pre-test was held on September 29,2018. After being tested, the result of pre-test was calculated by using Person Product Moment as below:
Table 1 . Analysis of student's pretest gained score between experiment and control group

\begin{tabular}{lccc}
\hline \multicolumn{1}{c}{ Group } & Mean & $\begin{array}{c}\text { Std } \\
\text { Deviation }\end{array}$ & $\begin{array}{c}\mathrm{P} \\
\text { Value }\end{array}$ \\
\hline Experiment & 467.143 & 1.199 .405 & 0.851 \\
& & & \\
\hline Control & 462.000 & 1.085 .682 & 0.851 \\
\hline
\end{tabular}


Based on the result of statistical computation, it can be seen that the mean of pretest experiment group is 46,7 while in opposite the control prestest score is 46,2. The result conclude that there is no high difference between the average. In other words, it can be said that the class is homogenous. The researcher applied t-test then he obtains significant value 0.851 . The result indicates that the two groups are homogenous.

Table 2. Analysis of student's postest gained score between experiment and control group

\begin{tabular}{lccc}
\hline \multicolumn{1}{c}{ Group } & Mean & $\begin{array}{c}\text { Std } \\
\text { Deviation }\end{array}$ & $\begin{array}{c}\mathrm{P} \\
\text { Value }\end{array}$ \\
\hline Experiment & 69.7429 & 13.3004 & .023 \\
& & & \\
\hline Control & 42.6571 & 12.12179 & .023
\end{tabular}

Based on the result of statistical computation, it can be seen that the mean of postest experiment group is 64.7 while in opposite the control prestest score is 42.6. And the significant value (2-tailed) 0.023 is lower than $\alpha 0.05$. The result conclude that there is relatively difference between the average. In other words, it can be said that after the posttest, the experimental score is higher than the control group. Thus the role play has significant influence on nurses's speaking ability.

\section{CONCLUSION}

The conclusion of this study is role play can be solusition toward nurses's speaking ability especially in Wiraraja University. The use of role play makes the students (nurse stidents) develop their speaking ability in easy way. They act as same as stakeholder in real live. So they can be familiar with some vocabularies that used to say in their proffesion commuication. Beside that, by using role play the students can explore their knowledge about medical treatment in English.

\section{REFERENCES}

Creswell, J. W. (2008). Research Design: Qualitative, quantitative, and mixed method approaches. SAGE Publications, Incorporated

Liu, F. \& Ding, Y (2009). Role Play in English language teaching. Asian Social Science, 5(10), 140-143

Qing, X (2011). Role Play an effective approach to developing overall comunicative competence. CrossCultural Commuication, 7(4), 36-39. DOI:10.3968/j.ccc.

Wilson, S. 1983. Living English Structure. London: Longman 